DESIGN FOR GOOD ACOUSTICS AND NOISE CONTROL 


\section{Design for Good Acoustics and Noise Control}

J. E. Moore, F.R.I.B.A. 


\section{J. E. Moore 1978}

Softcover reprint of the hardcover 1st edition 1978 978-0-333-24292-6

All rights reserved. No part of this publication may be reproduced or transmitted, in any form or by any means, without permission.

First published 1978 by

THE MACMILLAN PRESS LTD

London and Basingstoke

Associated companies in Delhi Dublin

Hong Kong Johannesburg Lagos Melbourne

New York Singapore and Tokyo

Typeset in 10/11 pt IBM Press Roman by

Reproduction Drawings Ltd, Sutton, Surrey

British Library Cataloguing in Publication Data

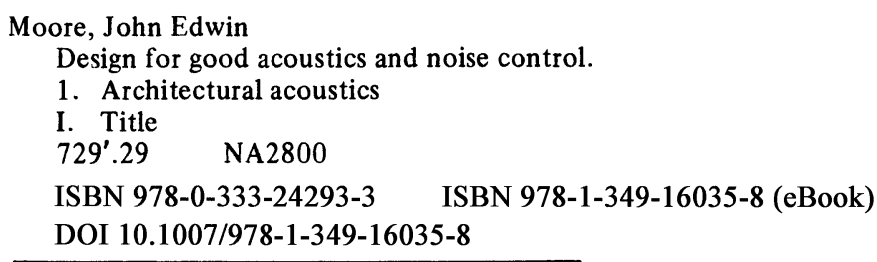

This book is sold subject to the standard conditions of the Net Book Agreement.

The paperback edition of this book is sold subject to the condition that it shall not, by way of trade or otherwise, be lent, resold, hired out, or otherwise circulated without the publisher's prior consent in any form of binding or cover other than that in which it is published and without a similar condition including this condition being imposed on the subsequent purchaser. 


\section{Contents}

Preface

Acknowledgements

viii

Section 1 Properties and Behaviour of Sound

Section 2 Subjective Aspects of Sound

Section 3 Noise Control

Section 4 Room Acoustics

Bibliography 205

Index 


\section{Preface}

This book has been written primarily as a textbook for students of architecture, interior design, town planning and surveying. With this broad purpose in mind I have attempted to provide in one volume of reasonable size as comprehensive a survey as possible of those acoustic factors which affect the design of rooms, buildings and urban development. This has meant dealing somewhat briefly with some aspects of the subject while other areas are discussed in more depth. The fairly extensive bibliography should, however, direct the student to further sources of study in those cases where space did not allow of a more detailed treatment. For example, I considered that an introduction to noise level contouring was all that was necessary since this technique is very fully described in inexpensive publications issued by the Department of the Environment.

I have also tried to arrange the material in a way that will make subsequent reference easy. There is first of all the broad division into four sections

(1) Properties and behaviour of sound

(2) Subjective aspects of sound

(3) Noise control

(4) Room acoustics.

In the last two sections principles and calculations are separated, again for easy reference. Calculations have been limited to those which I think the student will find most useful in design and which typify the methods employed.

Within this broad framework each subsidiary item has a clear subheading in the text and these are listed on a contents page at the beginning of each section. These pages, taken together, form an index that may often be more useful than the orthodox index at the end of the book. For example, it is possible for the reader to refresh his memory of a given item by following the thread of the subject through the four contents pages. If we take the phenomenon of 'screening' as a case in point, the reader will find this developed under the following subheadings:

Diffraction and sound shadows. Reduction of internal noise by screening.

Reduction of external noise by screening. Screening by planting. Effect of screening, single-figure calculations. Effect of screening, six-figure calculations. Acoustics for speech, sound shadows.

Finally, I have not assumed any previous knowledge of the physics of sound, building acoustics or even logarithmic scales. Many students will therefore find the earlier part of the book somewhat elementary but I considered it best not to allow any possible gaps in knowledge to hinder the understanding of the rest of the book. 


\section{Acknowledgements}

The author wishes to thank P. H. Parkin for permission to reproduce the graph in figure 3.40 . He is also very much indebted to the authors of many of the publications listed in the bibliography which were consulted during the preparation of this book. The schedules in table 3.14 are reproduced by permission of the Director of Her Majesty's Stationery Office. 